\title{
PENGEMBANGAN BAHAN AJAR MATEMATIKA BERBASIS VIDEO ANIMASI PADA KELAS III SD
}

\author{
${ }^{1}$ Dyana Utami, ${ }^{2}$ Yayah Huliatunisa, ${ }^{3}$ Boy Dorahman \\ Universitas Muhammadiyah \\ TangerangEmail : \\ utami.dyana24@gmail.com
}

\begin{abstract}
Abstrak
Penelitian ini bertujuan untuk mengembangkan bahan ajar berbasis video animasi pada mata pelajaran matematika. Jenis penelitian ini termasuk penelitian $R \& D$ (Research and Development) dengan menggunakan teori Borg and Gall. Hasil pengembangan media pembelajaran diketahui bahwa: (1) produk bahan ajar yang dikembangkan layak digunakan di SDIT Cordova 3. (2) kelayakan produk berdasarkan validasi ahli materi sebesar $(4,8)$ termasuk kriteria "sangat layak" untuk digunakan, sedangkan berdasarkan validasi ahli media sebesar $(4,3)$ termasuk kriteria "sangat layak" untuk digunakan. (3) hasil latihan I sebesar $(88,46 \%)$ termasuk kriteria "sangat tinggi", hasil latihan II sebesar $(84,61 \%)$ termasuk kriteria "tinggi", (4) bahan ajar yang dihasilkanmampu meningkatkan motivasi belajar.
\end{abstract}

Kata Kunci : Bahan ajar, video animasi, matematika SD

\begin{abstract}
This study aims to develop teaching materials based on animated videos in mathematics. . This type of research includes R\&D (Research and Development) research using the Borg and Gall theory. The results of the development of learning media are known that: (1) the product of teaching materials developed is suitable for use at SDIT Cordova 3. (2) the feasibility of the product based on the validation of the material expert is (4.8) including the "very feasible" criteriato be used, while based on expert validation media of (4.3) including the criteria of "very feasible"to be used. (3) the results of the first exercise $(88.46 \%)$ including the "very high" criteria, the second exercise results $(84.61 \%)$ including the "high" criteria, (4) the teaching materials producedare able to increase learning motivation.
\end{abstract}

Keywords: teaching materials, animated videos, elementary mathematics 


\section{PENDAHULUAN}

Berdasarkan hasil wawancara dan observasi yang dilakukan pada tanggal 29 Maret 2021 oleh peneliti dengan guru kelas yang mengajar di SDIT Cordova 3. Rendahnya minat belajar Matematika terlihat dari hasil ulangan harian siswa yang belum mencapai KKM, sedangkan nilaiKKM Matematika ditentukan 67, dari 25 siswa hanya 15 siswa atau 75\% yang mencapai KKM dan yang tidak mencapai KKM sebanyak 10 siswa atau 25\%. Penyebabnya diduga karena kegiatanpembelajaran masih berpusat pada guru, kurangnya pemahaman konsep Matematika dan tidak adanya inovasi lain sebagai bahan ajar selain buku cetak, serta tingkat partisipasi siswa masih rendah karena kurang terlibat dalam kegiatan pembelajaran. Oleh karena itu, perlu adanya pembaruan bahan ajar agar pemahaman konsep matematika dan motivasi belajar siswa dapat tercapai dengan baik.

Bahan ajar adalah seperangkat materi yang disusun secara sistematis sehingga tercipta lingkungan/suasana yang memungkinkan siswa belajar dengan baik. (Rosnaningsih, dkk, 2019 : 61). Bahan ajar adalah seperangkat materi pelajaran yang mengacu pada kurikulum yang digunakan dalam rangka mencapai standar kompetensi dan kompetensi dasar yang telah ditentukan. (Lestari dalam Nurdyansyah, 2018). Berdasarkan asumsi dari beberapa ahli di atas dapat disimpulkan bahwa bahan ajar merupakan seperangkat materi pelajaran baik tertulis maupuntidak tertulis yang digunakan untuk kegiatan belajar mengajar di kelas dengan mengacu pada kurikulum guna mencapai tujuan pembelajaran yang telah ditentukan.

Video animasi pembelajaran merupakan video animasi kartun yang dapat diisi oleh materi materipelajaran dan dapat dijadikan media pembelajaran untuk sekolah dasar karena sifatnya yang menarik dan terkesan lucu dan cocok untuk anak sekolah dasar. (Ismail, 2016). Menurut Arsyad dalam Purwanto dan Rizki (2015) Audio-Visual adalah penggambaran atau visualisasi dari narasimateri pembelajaran dan dikemas dengan singkat. Dari beberapa pendapat para ahli dapat disimpulkan bahwa video pembelajaran berbasis animasi adalah sebuah materi pembelajaran yangdikemas dengan penggambaran atau visualisasi yang ditampilkan dalam bentuk video animasi.

\section{METODE PENELITIAN}

Penelitian ini merupakan jenis penelitian R\&D, yang metode penelitiannya adalah menghasilkan produk tertentu, dan menguji keefektifan produk tersebut Sugiyono (2013:28). Produk yang dihasilkan dalam penelitian ini berupa media video pembelajaran pada mata pelajaran matematikauntuk siswa kelas 3 SDIT Cordova 3 Kecamatan Pasar Kemis, Kabupaten 
Tangerang. Model Penelitian ini menggunakan model Borg \& Gall. Teknik pengumpulan data pada penelitian ini dengan menggunakan lembar observasi, wawancara dengan guru kelas, dan angket respon siswa.Teknik analisis data yang digunakan pada penelitian ini menggunakan teknik analisis deskriptif dengan menghitung skor yang diperoleh.

\section{Langkah-langkah penelitian pengembangan}

1. Penelitian \& Pengumpulan Informasi Awal (Research and Information Collecting)

Peneliti melakukan studi pendahuluan atau studi eksploratif untuk mengkaji, menyelediki, dan mengumpulkan informasi.

2. Perencanaan (Planning)

Peneliti membuat rencana desain pengembangan produk. Aspek-aspek penting dalam rencana tersebut meliputi produk tentang apa, tujuan dan manfaatnya apa, siapa pengguna produknya, mengapa produk tersebut dianggap penting, dimana lokasi untuk pengembangan produk dan bagaimana proses pengembangannya.

3. Pengembangan Format Produk Awal (Develop Preliminary Form of Product)

Peneliti mulai mengembangankan bentuk produk awal yang bersifat sementara (hipotesis). Produk yang dibuat lengkap dan sebaik mungkin, seperti kelengkapan komponenkomponen program, petunjuk pelaksanaan (juklak), petunjuk teknis (juknis), contoh-contoh soal atau latihan, media pembelajaran yang akan digunakan, dan sistem penilain.

\section{Uji Coba Awal (Preliminary Field Testing)}

Peneliti melakukan uji coba terbatas mengenai produk awal di lapangan yang melibatkan antarasekolah dengan subjek antara 10-15 orang. Selama uji-coba berlangsung, peneliti dapat melakukan observasi terhadap kegiatan subjek (guru) dalam melaksanakan produk tersebut. Setelah selesai uji-coba, kemudian peneliti melakukan diskusi dengan subjek. Peneliti juga dapat memberikan angket kepada subjek.

5. Revisi Produk (Main Product Revision)

Melakukan revisi tahap pertama, yaitu perbaikan dan penyempurnaan terhadap produk utama,berdasarkan hasil uji-coba terbatas, termasuk hasil diskusi, observasi, wawancara, dan angket.

6. Uji Coba Lapangan (Main Field Testing)

Melakukan uji-coba produk dengan skala yang lebih luas. Perkiraan sekolah yang terlibat antaralima sampai dengan sepuluh sekolah serta subjek antara 30 sampai dengan 100 orang.

\section{Revisi Produk (Operational Product Revision)}

Melakukan revisi tahap kedua, yaitu memperbaiki dan menyempurnakan produk 
berdasarkan masukan dan saran-saran hasil uji-coba lapangan yang lebih luas.

\section{Uji coba produk}

\section{Desain Uji Coba}

Dalam penelitian ini, uji coba dilakukan dua kali, yaitu (a) uji-ahli (expert judgement) untuk menguatkan dan meninjau ulang produk awal serta memberikan masukan perbaikan, yaitu validator yang dilakukan ahli.

2. Subjek Uji Coba

a. Subjek validasi

Subjek validasi terdiri dari 2 dosen matematika dan 1 guru mata pelajaran matematika.

1.) Dosen validator : (1) Dosen jurusan teknologi informatika dan telah menempuh jenjangS-2 pada program studi teknologi informatika.

2.) Guru matematika : Guru matematika yang sudah berpengalaman mengajar matematika,dan pendidikan minimal S-1 program pendidikan matematika.

b. Subjek Uji Coba

Sampel yang akan menjadi uji coba adalah siswa SDIT Cordova 3. Penelitian ini meliputi dua kelas III-jeddah. Jumlah siswa kelas III-jeddah yaitu 26 siswa.

3. Teknik analisis data

a. Analisis Kualitatif

Analisis kualitatif digunakan untuk mendeskripsikan hasil observasi, wawancara, saran dosen validasi, angket minat belajar siswa setelah menggunakan produk dan catatandokumentasi saat diimplementasikan.

b. Analisis Kuantitatif

Analisis kuantitatif digunakan untuk mendeskripsikan kualitas bahan ajar berdasarkan penilaian dosen ahli media dan guru mata pelajaran matematika serta mendeskripsikan hasil belajar siswa setelah menggunakan media pembelajaran video animasi.

\section{HASIL DAN PEMBAHASAN}

\section{Hasil validasi ahli media}

Uji kelayakan ini dilakukan oleh Dosen Pendidikan Guru Sekolah Dasar FKIP UMT yaitu ArryPatriasurya. Berikut analisis data penilaian validasi ahli materi disajikan pada Tabel 1. 
http://jurnal.umt.ac.id/index.php/lJOEE

\begin{tabular}{|c|c|c|c|c|}
\hline No & Aspek Penilaian & $\begin{array}{l}\text { Jumlah Butir } \\
\text { (n) }\end{array}$ & $\begin{array}{l}\text { Skor yang diperoleh } \\
\text { (x) }\end{array}$ & Kriteria $(\bar{x})$ \\
\hline 1. & $\begin{array}{l}\text { Perlunya pengembangan bahan } \\
\text { ajar berbasis video animasi }\end{array}$ & 1 & 3 & \multirow{4}{*}{$\begin{array}{c}\bar{x}=\begin{array}{c}\sum X \\
n\end{array} \\
\bar{X}=\frac{43}{10}=4,3\end{array}$} \\
\hline 2. & $\begin{array}{l}\text { Video animasi menarik minat } \\
\text { belajar siswa }\end{array}$ & 4 & 15 & \\
\hline 3. & Kualitas tampilan video & 3 & 15 & \\
\hline 4. & $\begin{array}{l}\text { Kesesuaian kontras warna dengan } \\
\text { audiensi }\end{array}$ & 2 & 10 & \\
\hline & Jumlah & 10 & 43 & Sangat Layak \\
\hline
\end{tabular}

Berdasarkan tabel kriteria analisis data penilaian validasi ahli media didapatkan jumlah skor sebesar 43 pada 10 butir pernyataan. Rata-rata perolehan skor adalah 4,3 masuk pada kriteria "sangat layak"

Hasil validasi ahli materi

Uji kelayakan ini dilakukan oleh Guru Matematika di SDIT Cordova 3 yaitu Muhammad KhuluqinHasan. Berikut analisis data penilaian validasi ahli materi disajikan pada Tabel 2.

Tabel 2 Analisis Data Penilaian Ahli Materi

\begin{tabular}{|c|c|c|c|c|}
\hline No & Aspek Penilaian & $\begin{array}{c}\text { Jumlah Butir } \\
\text { (n) }\end{array}$ & $\begin{array}{c}\text { Skor yang diperoleh } \\
(\mathbf{x})\end{array}$ & Kriteria $(x$ \\
\hline 1. & $\begin{array}{l}\text { Kesesuaian materi pada SK } \\
\text { dan KD }\end{array}$ & 1 & 3 & \multirow{4}{*}{$\begin{array}{c}\bar{x}=\frac{\sum X}{n} \\
\bar{x}=\frac{48}{10}=4,8\end{array}$} \\
\hline 2. & $\begin{array}{l}\text { Ketepatan dalam materi } \\
\text { pembelajran }\end{array}$ & 3 & 15 & \\
\hline 3. & $\begin{array}{l}\text { Keefektifan belajar mengajar } \\
\text { menggunakan bahan ajar } \\
\text { konstektual }\end{array}$ & 5 & 25 & \\
\hline 4. & $\begin{array}{l}\text { Penggunaan Bahasa pada } \\
\text { video animasi }\end{array}$ & 1 & 5 & \\
\hline & Jumlah & 10 & 48 & Sangat Layak \\
\hline
\end{tabular}

Berdasarkan tabel kriteria analisis data penilaian validasi ahli media didapatkan jumlah skor sebesar 48 pada 10 butir pernyataan. Rata-rata perolehan skor adalah 4,8 masuk pada kriteria "sangat layak" 


\section{Hasil belajar siswa pada latihan 1}

Penilaian ini dilakukan saat implementasi di kelas III SDIT Cordova 3 pada Latihan I. Berikutanalisis data penilaian hasil belajar siswa pada latihan I disajikan pada Tabel 3. Tabel 3 Analisis Data Penilaian Hasil Belajar pada Latihan I

\begin{tabular}{|c|c|c|}
\hline Interval Nilai & Frekuensi (f) & Kriteria $(\bar{x})$ \\
\hline$\geq 75$ & 23 & $-x=\frac{\sum \text { siswa yang tuntas }}{\sum \text { siswa }} \times 100 \%$ \\
\hline$\leq 75$ & 3 & $-x=\frac{23}{26} 100 \%=88,46$ \\
\hline Jumlah & $\mathbf{2 6}$ & "Sangat Tinggi" \\
\hline
\end{tabular}

Tabel 3 menunjukan bahwa dari 26 siswa yang mengikuti tes didapatkan jumlah siswa yang memiliki nilai sama atau lebih dari 75 adalah 23 siswa, sedangkan jumlah siswa yang memiliki nilai kurang dari 75 adalah 3 siswa. Berdasarkan tabel 11 (Interval ketuntasan belajar siswa halaman 45) persentase ketuntasan sebesar $88,46 \%$ termasuk dalam kriteria "sangat tinggi" yaituberada pada kisaran $84-100 \%$.

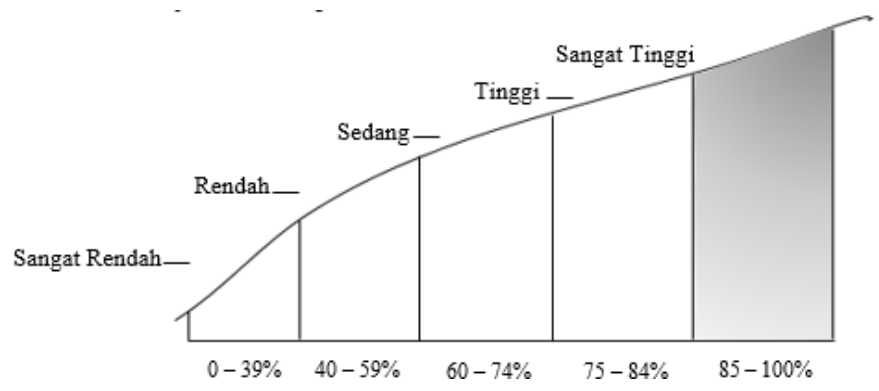

Gambar 1 Kurva Hasil Penilaian Siswa Pada Latihan I

\section{Hasil belajar siswa pada latihan 2}

Penilaian ini dilakukan saat implementasi di kelas III di SDIT Cordova 3 pada Latihan 2. Berikutanalisis data penilaian hasil belajar siswa pada latihan 2 disajikan pada Tabel 4. 
Tabel 4 Analisis Data Hail Penilaian Siswa pada Latihan II

\begin{tabular}{|c|c|c|}
\hline Interval Nilai & Frekuensi (f) & Kriteria $(\bar{x})$ \\
\hline$\geq 75$ & 22 & $-\bar{x}=\frac{\sum \text { siswa yang tuntas }}{\sum \text { siswa }} \times 100 \%$ \\
$\leq 75$ & 4 & $-x=\frac{22}{26} \times 100 \%=84,61$ \\
\hline Jumlah & $\mathbf{2 6}$ & "Tinggi" \\
\hline
\end{tabular}

Tabel 4 menunjukan bahwa dari 26 siswa yang mengikuti tes didapatkan jumlah siswa yang memiliki nilai sama atau lebih dari 75 adalah 24 siswa, sedangkan jumlah siswa yang memiliki nilai urang dari 75 adalah 4 siswa. Persentase ketuntasansebesar 84,61\% termasuk dalam kriteria “ tinggi” yaitu berada pada kisaran $75 \%-84 \%$.

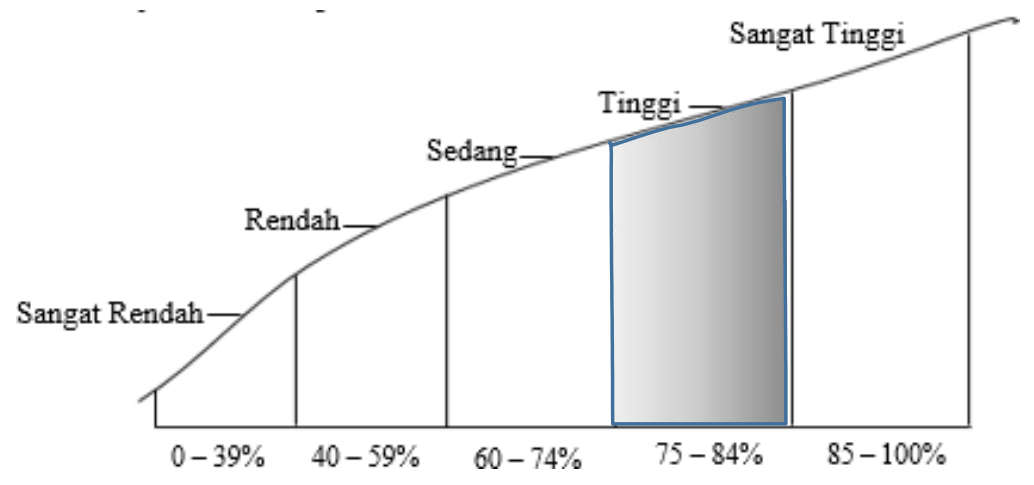

Gambar 2 Kurva Hasil Penilaian Siswa Pada Latihan 2

Hasil minat belajar siswa

Adapun hasil penilaian minat belajar siswa setelah menggunakan media dapat dilihat pada lampiran 14. Berikut tabel analisis penilaian minat belajar siswa kelas III Muzdalifah SDIT Cordova 3 setelah menggunakan bahan ajar berbasis video animasi disajikan pada Tabel 5 .

Tabel 5 Analisis Data Minat Belajar Siswa

\begin{tabular}{|l|l|c|l|}
\hline No & \multicolumn{1}{|c|}{ Indikator } & $\begin{array}{c}\text { Jumlah } \\
\text { Butir }\end{array}$ & \multicolumn{1}{|c|}{ Keterangan } \\
\hline 1. & Keingintahuan & 3 & $\begin{array}{l}\text { 24 siswa berpendapat "YA" dan 2 siswa } \\
\text { berpendapat "TIDAK" }\end{array}$ \\
\hline 2. & Rasa senang & 2 & 26 siswa bepndapat "YA" \\
\hline 3. & Perhatian & 2 & 26 siswa berpendapat "YA" \\
\hline
\end{tabular}




\begin{tabular}{|l|l|c|l|}
\hline 4. & Ketertarikan & 3 & 26 siswa berpendapat "YA" \\
\hline Jumlah Butir & 10 & \\
\hline
\end{tabular}

Berdasarkan data diatas dapat disimpulkan bahwa dari 26 siswa terdapat lebih dari 3 point indikator yang memberikan respon positif, maka hasilnya adalah siswa "sangat berminat" belajarmenggunakan video animasi terutama dalam pembelajaran matematika.

\section{SIMPULAN DAN SARAN}

\section{Kesimpulan}

Berdasarkan pertanyaan penelitian pada pengembangan media pembelajaran berbasis videoanimasi, maka dapat diambil simpulan sebagai berikut:

1. Pengembangan bahan ajar berbasis video animasi pada mata pelajaran matematika mengacu pada model pengembangan Borg and Gall yang telah diadaptasikan menjadi 7 langkah yaitu pengumpulan informasi awal, perencanaan, pengembangan produk awal, ujicoba awal, revisi produk, uji coba lapangan, uji coba akhir. Ujicoba awal dilakukan pada7 orang siswa kelas III yang sedang mempelajari materi Satuan Berat dan Satuan Waktu dan implementasi dilakukan pada siswa kelas III-Jeddah. Produk bahan ajar yang dikembangkan pada penelitian ini layak digunakan di SDIT Cordova 3 karena telah memenuhi indikator keberhasilan produk.

2. Kelayakan bahan ajar berbasis video animasi pada mata pelajaran matematika didapatkandari hasil penilaian ahli materi dan ahli media. Hasil penilaian ahli materi memperoleh rata-rata skor 4,8 termasuk pada kriteria "sangat layak" untuk digunakan di SDIT Cordova 3.

Hasil penilaian ahli media memperoleh rata-rata skor 4,3 termasuk pada kriteria "sangat layak" untuk digunakan di SDIT Cordova 3.

3. Ketuntasan hasil belajar siswa diperoleh dari 2 nilai tes yang dilakukan yaitu Ketuntasan hasil belajar siswa pada tahap latihan 1 didapatkan persentase ketuntasan $88,46 \%$ termasuk pada kriteria "sangat tinggi". Pada tahap latihan 2 didapatkan persentase ketuntasan84,61\% termasuk pada kriteria "tinggi".

4. Minat belajar siswa setelah menggunakan media mengalami peningkatan yaitu pada siswakelas III-Jeddah terdapat lebih dari $50 \%$ yang memberikan hasil positif pada angket termasuk pada kriteria "sangat berminat" untuk belajar matematika. 


\section{Saran}

Berdasarkan hasil penelitian dan pengembangan bahan ajar berbasis video animasi ini, makapeneliti memberikan saran sebagai berikut :

1. Produk pengembangan bahan ajar berbasis video animasi ini dapat digunakan sebagai alternatif pilihan yang dapat diperhitungkan untuk pembelajaran pada mata pelajaran matematika.

2. Kerja sama TIM antara guru dengan pengembang bahan ajar menjadi sangat penting gunamenghasilkan bahan ajar yang menarik dan sesuai dengan karakteristik siswa.

3. Pengembang bahan ajar dapat menambahkan materi-materi matematika yang lain sehinggatidak hanya pada materi satuan berat dan satuan waktu saja.

4. Perlu adanya pendanaan yang dilakukan baik itu pemerintah maupun swasta saling bekerjasama guna mendukung pemerataan fasilitas di setiap sekolah sehingga bahan ajar berbasisvideo animasi ini dapat digunakan tanpa adanya keterbatasan fasilitas yang dimilikisekolah.

5.

\section{DAFTAR PUSTAKA}

Adkhar, B. I. (2016). Pengembangan media video animasi pembelajaran berbasis powtoon pada kelas 2 mata pelajaran Ilmu Pengetahuan Alam di SD Labschool UNNES. Jurnal Pendidikan, 36-39.

Andriani, R., \& Rasto. (2019). Motivasi belajar sebagai determinan hasil belajar siswa. Jurmal Pendidikan Manajemen Perkantoran, 81-82.

Apriansyah, M. R., Sambowo, K. A., \& Maulana, A. (2020). Pengembangan media pembelajaran video berbasis animasi mata kuliah Ilmu Bahan Bangunan di program studi Teknik Bangunan Fakultas Teknik Universitas Negeri Jakarta. Jurnal Pendidikan Teknik Sipil, 4.

Arsanti, M. (2018). Pengembangan bahan ajar mata kuliah penulisan kreatif bermuatan nilai-nilai pendidikan karakter religius bagi mahasiswa Prodi PBSI, FKIP, UNISSULA. Jurnal Kredo, 4-5.

Asih Rosnaningsih, M., Candra Puspita Rini, M., \& Asharini Septi Wulandari, M. (2018). Perencanaan Pembelajaran. Tangerang: CV. El Nisa Media Utama.

Dimyati, \& Mudjiono. (2018). Belajar \& Pembelajaran. Jakarta: PT. Rineka Cipta.

Heruman. (2010). Model Pembelajaran Matematika di Sekolah Dasar. Bandung: PT. Remaja 
Rosdakarya.

Rahmah, N. (2013). HAKIKAT PENDIDIKAN MATEMATIKA.

Hakikat pendidikan matematika.

Sadirman. (2016). Ineraksi \& Motivasi Belajar Mengajar. Jakarta: PT. RajaGrafindo Persada.

Setiawan, D. (2012). Pengembangan Bahan Ajar. Tangerang Selatan: Penerbit Universitas Terbuka. 